\title{
Development of PCR Assay for Identification of Staphylococcus Aureus and their Enterotoxins from Spoiled Food Samples
}

\author{
${ }^{1}$ Noor Nihad Abdul Hussein, ${ }^{2}$ Mondeddu Kiran Kumar, ${ }^{3}$ Dr. Varun Kumar Sharma \\ ${ }^{1}$ Pharmacy College, Baghdad University, Bab almoudham, Baghdad, Iraq \\ ${ }^{2,3}$ Noida International University, Gautam Budh Nagar, U. P, India \\ Email:noor.n.ameen@gmail.com, kiranreddy.m17@gmail.com
}

Received: 20 ${ }^{\text {th }}$ October 2018, Accepted: 28 ${ }^{\text {th }}$ November 2018, Published: $3^{\text {st }}$ December 2018

\begin{abstract}
Food-borne diseases due to microbial pathogens, have become a major issue of concern as they represent serious threat to the health of millions of people world - wide. Serious outbreaks of food borne disease have been documented on every continent in the past decades, illustrating both the public health and social significance of these diseases. ${ }^{[3,4]}$ Food Contamination is of major health hazards in India leading to food poisoning. The food borne diseases due to food contamination or spoilage is one of the important problems to be addressed. Staphylococcus aureus has been found to be one of the major cause of food poisoning among all the other food pathogens.

$S$. aureus produces very important virulence factors including Staphylococcus enterotoxins (SEs) which are the main causes of diarrhoea, vomiting and other symptoms associated with food poisoning. ${ }^{[2,5,8]}$ Therefore to minimize infection in food and water, the etiological agents and harmful toxins produced by them must be identified. Early identification will be helpful in minimizing food borne infections which helps in the prevention of diarrheal diseases. The conventional methods used for identification of $S$.aureus are limited to their Biological characterization only that are not only time consuming rather have limited reliability. ${ }^{[1,6]}$ Currently the molecular techniques based on PCR amplification of $16 \mathrm{~S}$ rRNA of S.aureus for rapid and specific detection is widely used approach. This study focuses on rapid detection of S.aureus strains obtained from various food samples by development of a specific PCR Assay including a novel primer set and standardized PCR Conditions. A multiplex PCR assay has also been developed for specific Staphylococcal enterotoxins genes (SEA, SEB, SEC, SED, and SEE) produced by different isolates. Out of the 59 isolates of Staphylococcus aureus obtained from various food samples, found positive for enterotoxin infection, $15,21,6,12$ and 5 were found to be producing SEA, SEB, SEC, SED and SEE respectively further employing that these strains were capable of producing only one type of enterotoxin. The developed multiplex polymerase chain reaction assays will be useful for rapid detection of $S$. aureus and respective enterotoxins being produced from foods, clinical samples and environmental surveys. This may lead to early diagnosis of infection and help in timely prophylaxis.
\end{abstract}

\section{Keywords}

Staphylococcus aureus, PCR Assay, Enterotoxin, Food Poisoning, SEA, SEB, SEC, SED, SEE.

\section{Introduction}

With the rapid increase in the out breaks of food poisoning Surveillance of food borne diseases is of an increasingly high priority in the public health agenda worldwide. Among all, Staphylococcus aureus is one of the most common clinical and food borne pathogen. It is reported that more than $70 \%$ of $S$. aureus strains produced one or more enterotoxins. ${ }^{[7]}$ Staphylococcus aureus is a major human pathogen and causes a variety of food borne infections, nosocomial and community acquired infections. ${ }^{[11]}$ Because of their thermal stability they remain a great hazard even in heat processed foods. Multiplex PCR were developed to detect S. aureus toxin for SEA, SEB, SEC, SED and SEE. All these toxins show emetic activity on humans. The 16S rRNA gene of Staphylococcus contain DNA sequence that are highly conserved at genus level but variable among other bacterial genera. The primer pair used in a study has been shown to be conserved in 19 Staphylococcus species and subspecies ${ }^{[2,3]}$ therefore combined detection of $16 \mathrm{~S}$ rRNA and all the five Staphylococcal enterotoxin genes may be a reliable set of markers for the detection of Staphylococcus aureus. Primers designed for 16S rRNA gene for Staphylococcus will be a useful tool for identification and confirmation of Staphylococcus species.

\author{
Materials and Methods \\ from different food stores in and around Hyderabad \\ i. $\quad$ Milk and Milk products- e g cheese, butter, milk sweets, raw milk, curd \\ ii. Meat and Meat products - e g non-veg burgers and soups, chicken, mutton
}

Sample Collection and Processing: A total of 75 food samples classified into following three groups were collected 
iii. Ready to eat food- e g cakes, pastries, sandwiches

The criterion of inclusion was the selection of perishable food items with defined expiry dates. While their selection it was made a mandate that the food items should not have crossed the expiry dates. Cereals, oils, pickles, ketchups, dry fruits and other such food stuffs that can be stored for long were excluded.

All these food samples were deliberately allowed to get contaminated by random bacteria by incubating them for 1-2 weeks at room temperature and were detected for Staphylococcus aureus phenotypically followed by bacteriological examinations.

Preparation of Food Samples and Isolation of Staphylococcus aureus: 10gm of each collected food samples was aseptically weighed and macerated and $10 \mathrm{ml}$ of sterile distilled water was added to them to perform serial dilution. Master plates were made in Nutrient Agar media for all of the 75 samples from $10^{-10}$ dilution by pour plate or spread plate method.

Identification of $\boldsymbol{S}$ aureus by Gram's Staining and Biochemical Characterization: From all of the master plates prepared a total of 100 isolated Colonies showing the characteristic morphology of smooth and circular yellow colonies were further sub cultured and Gram stained. 72 isolates were showing gram positive cocci in groups that were further biochemically characterized. ${ }^{[9]} \mathrm{A}$ total of 64 such isolates gave positive biochemical characterization as that of S aureus. The results are summarised as follows:

\begin{tabular}{|l|l|}
\hline Culture Medium & Results Observed \\
\hline Nutrient Agar medium & Yellow pigmented circular colonies with smooth surface \\
\hline Gram Staining & Positive coccus \\
\hline Biochemical Tests & Results Observed \\
\hline Catalase & Positive; showing brisk effervescence, bubbles of oxygen observed \\
\hline Coagulase & Clot formation observed \\
\hline DNase & Clear zone around the colony \\
\hline MR & Development of stable red color \\
\hline $\begin{array}{l}\text { Mannitol fermentation (phenol red } \\
\text { indicator) }\end{array}$ & $\begin{array}{l}\text { Turns yellow due to acid production and bubble appeared in durhams } \\
\text { tube due to gas production }\end{array}$ \\
\hline
\end{tabular}

Table 1: Showing Morphological and Biochemical Characters of S. aureus

Extraction of Genomic DNA: 500ml of LB broth was prepared and all of the 64 isolates were inoculated separately in it and incubated at $37^{\circ} \mathrm{C}$ for $18-24 \mathrm{hrs}$.

$1.5 \mathrm{ml}$ of each culture was taken and centrifuged at 10000rpm for $10 \mathrm{mts}$. The supernatant was discarded and 500ul of lysis buffer ( $50 \mathrm{mM}$ Tris $\mathrm{HCl}, 20 \mathrm{mM}$ EDTA, $1.5 \% \mathrm{SDS}$ ) was added to each of the 64 pellets. All of them were gently vortexed and incubated at $60-65^{\circ} \mathrm{C}$ for $20 \mathrm{mts}$ with gentle vortex at every $10 \mathrm{mts}$. They were cooled to room temperature and $50 \mathrm{ul}$ of $3 \mathrm{M}$ sodium acetate was added to each. They were kept in ice cold condition for $10 \mathrm{mts}$ to prevent exothermic reaction and centrifuged at 10000rpm for $10 \mathrm{mts}$. To the supernatant equal volume of Isopropyl alcohol was added and kept in ice cold condition for $1 / 2 \mathrm{hr}$. They were again centrifuged at $12000 \mathrm{rpm}$ for $10 \mathrm{mts}$. The collected pellets were air dried and 50ul of TE buffer was added to each of them.

Primer Designing and Assay Development: Novel primers were designed for amplification of 16S rRNA gene of S.aureus as well as five different SEs by using Primer BLAST and Primer3 Tools. The two sets of primers for each of the gene were standardized and the optimum PCR conditions were designed for them. In multiplex PCR more than one DNA sequence are simultaneously amplified as if many separate PCR reactions are performing all together in one reaction. This process amplifies DNA in samples using multiple primers and a temperature-mediated DNA polymerase in a thermal cycler. All of the primer pairs have to be optimized so that all of them can work at the same annealing temperature during PCR.

The PCR assay is developed by performing different gradients for temperature, time and number of cycles for denaturation, annealing and extension steps of PCR.

\begin{tabular}{|c|c|c|c|c|}
\hline \multirow{2}{*}{$\begin{array}{l}\text { S No } \\
1\end{array}$} & \multirow{3}{*}{$\begin{array}{l}\text { Gene } \\
16 \mathrm{~S} \\
\text { rRNA }\end{array}$} & Tool & \multicolumn{2}{|c|}{ Sequence } \\
\hline & & \multirow[t]{2}{*}{ Primer BLAST } & FWD & CACCTTCCGATACGGCTACC \\
\hline & & & REV & CGTCAAATCCCATCATGCCC \\
\hline & & \multirow[t]{2}{*}{ Primer 3} & FWD & GAAAGCCACGGCTAACTACG \\
\hline & & & REV & CATTTCACCGCTACACATGG \\
\hline \multirow[t]{4}{*}{2} & \multirow[t]{4}{*}{ SEA } & \multirow[t]{2}{*}{ Primer BLAST } & FWD & ACCAACGGTTCTTTTGAGGT \\
\hline & & & REV & GCATCAGAACTGTTGTTCCGC \\
\hline & & \multirow[t]{2}{*}{ Primer 3} & FWD & TCAGAACTGTTGTTCCGCTAGA \\
\hline & & & REV & AACCAACGGTTCTTTTGAGG \\
\hline \multirow[t]{2}{*}{3} & \multirow[t]{2}{*}{ SEB } & \multirow[t]{2}{*}{ Primer BLAST } & FWD & ACTCGCCTTATGAAACGGGA \\
\hline & & & REV & CTGGTGCAGGCATCATGTCA \\
\hline
\end{tabular}




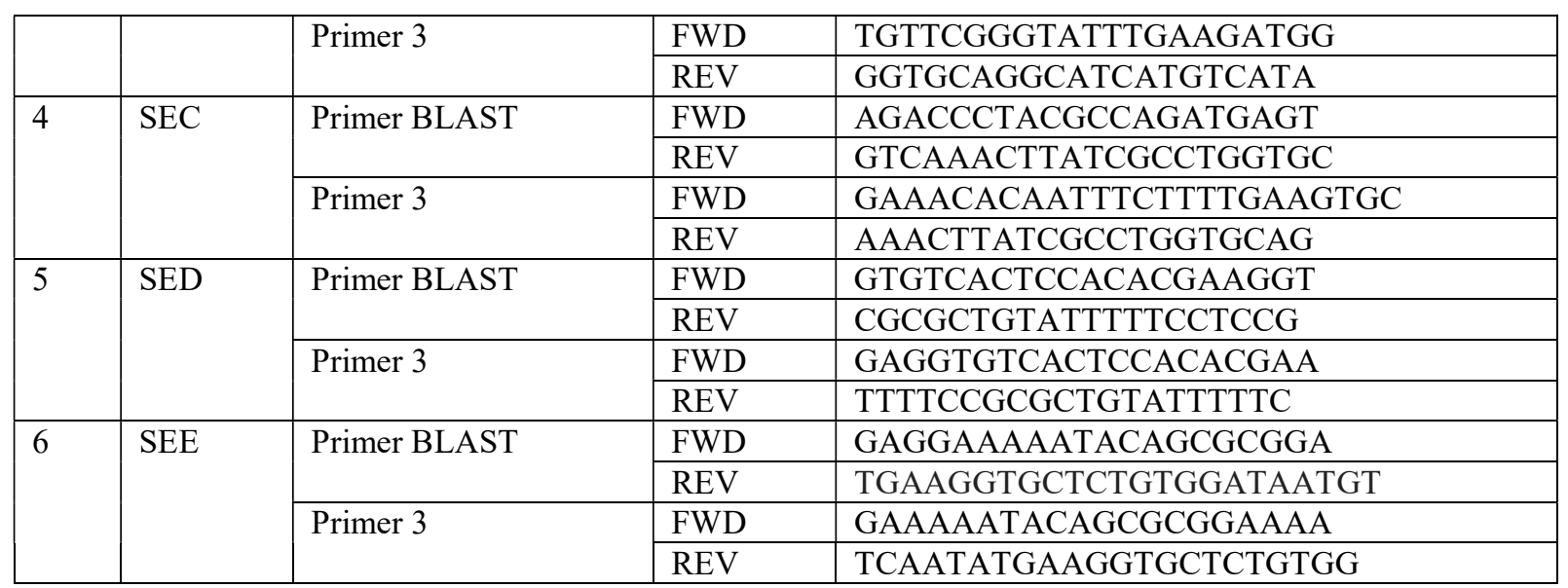

Table 2: Showing Output of Primer Designing Tools for 16S rRNA and Enterotoxins of $S$. aureus

PCR Amplification: Five groups of 64 gDNA samples each were made and each sample within a group was amplified with primer of one of the enterotoxin along with that of the $16 \mathrm{~S}$ rRNA gene. The reaction mixtures consists of $2 \mu 1$ of extracted DNA template from the bacterial isolates, $5 \mu 1$ of 10X PCR Buffer [containing $75 \mathrm{mM}$ Tris $\mathrm{HCl}$, with pH 9.0, $2 \mathrm{mM} \mathrm{MgCl} 2,50 \mathrm{mM} \mathrm{KCl}, 20 \mathrm{mM}(\mathrm{NH} 4)_{2} \mathrm{SO}_{4}, 1 \mu \mathrm{dNTPs}(40 \mathrm{M}), 1 \mu \mathrm{l}$ of $1 \mathrm{U}$ Ampli Taq DNA polymerase], $1 \mu 1$ (50pmol) each of forward and reverse primers. ${ }^{[10]}$ The volume of the reaction mixture was made up to $50 \mu 1$ using double distilled water. For all the novel primer designed the temperature, time and number of cycles for PCR were standardized to develop the assays. The PCR products were tested for positive amplification on $1.2 \%$ Agarose gel electrophoresis using $1 \mathrm{~Kb}$ molecular weight marker and checked under Transilluminator of the Gel Documentation System.

\section{Results and Discussion}

A total of 12 pairs of Primers were obtained from the two tools used for Primer designing. Considering the maximum product length and minimum GC content following set of primers were short listed for the target six genes:

\begin{tabular}{|c|c|c|c|c|c|c|}
\hline $\begin{array}{l}\mathrm{S} \\
\text { No }\end{array}$ & Gene & Tool & Sequence & $\begin{array}{l}\text { Meltin } \\
\text { g point }\end{array}$ & GC\% & $\begin{array}{l}\text { Product } \\
\text { Length }\end{array}$ \\
\hline \multirow[t]{2}{*}{1} & \multirow{2}{*}{$\begin{array}{l}16 \mathrm{~S} \\
\text { rRNA }\end{array}$} & \multirow{2}{*}{$\begin{array}{l}\text { Primer } \\
\text { BLAST }\end{array}$} & CACCTTCCGATACGGCTACC & 59.97 & 60 & \multirow[t]{2}{*}{1248} \\
\hline & & & CGTCAAATCCCATCATGCCC & 59.33 & 55 & \\
\hline \multirow[t]{2}{*}{2} & \multirow[t]{2}{*}{ SEA } & \multirow[t]{2}{*}{ Primer 3} & TCAGAACTGTTGTTCCGCTAGA & 60.05 & 45.45 & \multirow[t]{2}{*}{245} \\
\hline & & & AACCAACGGTTCTTTTGAGG & 59.07 & 45 & \\
\hline \multirow[t]{2}{*}{3} & \multirow[t]{2}{*}{ SEB } & \multirow[t]{2}{*}{ Primer 3} & TGTTCGGGTATTTGAAGATGG & 59.81 & 42.86 & \multirow[t]{2}{*}{247} \\
\hline & & & GGTGCAGGCATCATGTCATA & 60.51 & 50 & \\
\hline \multirow[t]{2}{*}{4} & \multirow[t]{2}{*}{ SEC } & \multirow{2}{*}{$\begin{array}{l}\text { Primer } \\
\text { BLAST }\end{array}$} & AGACCCTACGCCAGATGAGT & 60.03 & 55 & \multirow[t]{2}{*}{156} \\
\hline & & & GTCAAACTTATCGCCTGGTGC & 59.87 & 52.38 & \\
\hline \multirow[t]{2}{*}{5} & \multirow[t]{2}{*}{ SED } & \multirow[t]{2}{*}{ Primer 3} & GAGGTGTCACTCCACACGAA & 59.71 & 55 & \multirow[t]{2}{*}{324} \\
\hline & & & TTTTCCGCGCTGTATTTTTC & 60.21 & 40 & \\
\hline \multirow[t]{2}{*}{6} & \multirow[t]{2}{*}{ SEE } & \multirow[t]{2}{*}{ Primer 3} & GAAAAATACAGCGCGGAAAA & 60.21 & 40 & \multirow[t]{2}{*}{276} \\
\hline & & & TCAATATGAAGGTGCTCTGTGG & 60.13 & 45.45 & \\
\hline
\end{tabular}

Table 3: Showing Details of Short Listed Primers Designed for 16S rRNA and Enterotoxins of $S$. aureus Assay was developed for all the six sets of amplifications as follows:

\begin{tabular}{|l|l|l|l|}
\hline Step & Temperature & Time & No. of Cycle \\
\hline Initial denaturation & $94^{\circ} \mathrm{C}$ & $3 \mathrm{~min}$ & 1 \\
\hline Denaturation & $94^{\circ} \mathrm{C}$ & $30 \mathrm{sec}$ & \multirow{2}{*}{} \\
\hline Annealing & $56^{\circ} \mathrm{C}$ & $45 \mathrm{sec}$ & \multirow{2}{*}{} \\
\hline Extension & $72^{\circ} \mathrm{C}$ & $90 \mathrm{sec}$ & 1 \\
\hline Final Extension & $72^{\circ} \mathrm{C}$ & $5 \mathrm{~min}$ & 1 \\
\hline Hold & $4^{\circ} \mathrm{C}$ & Indefinitely & 1 \\
\hline
\end{tabular}

Table 4: PCR Cycle Conditions for 16S rRNA and Enterotoxins Amplification

Out of all the 64 isolates in each of the five groups 61 samples gave positive amplification results with 16S rRNA primer in each group revealing that only 61 isolates were S. aureus, remaining three might be any other species of Staphylococcus. Out of these 61, 59 got successfully amplified with any one of the enterotoxins also summarized as follows: 


\begin{tabular}{|l|l|l|}
\hline Group No. & Primers Used & No. of positive isolates \\
\hline 1 & 16 S rRNA + SEA & 15 \\
\hline 2 & 16 S rRNA + SEB & 21 \\
\hline 3 & 16 S rRNA + SEC & 6 \\
\hline 4 & 16 S rRNA + SED & 12 \\
\hline 5 & 16 S rRNA + SEE & 5 \\
\hline \multicolumn{2}{|r|}{ Total } & 59 \\
\hline
\end{tabular}

Table 5: Number of Isolates Producing Specific Enterotoxin

An important point to be noted here was none of the isolate were found to be positive for more than one enterotoxins employing that all of the $\mathrm{S}$ aureus strains obtained in the work were highly specific for Type of enterotoxins being produced while two of them did not show any amplicons for any of the enterotoxin.

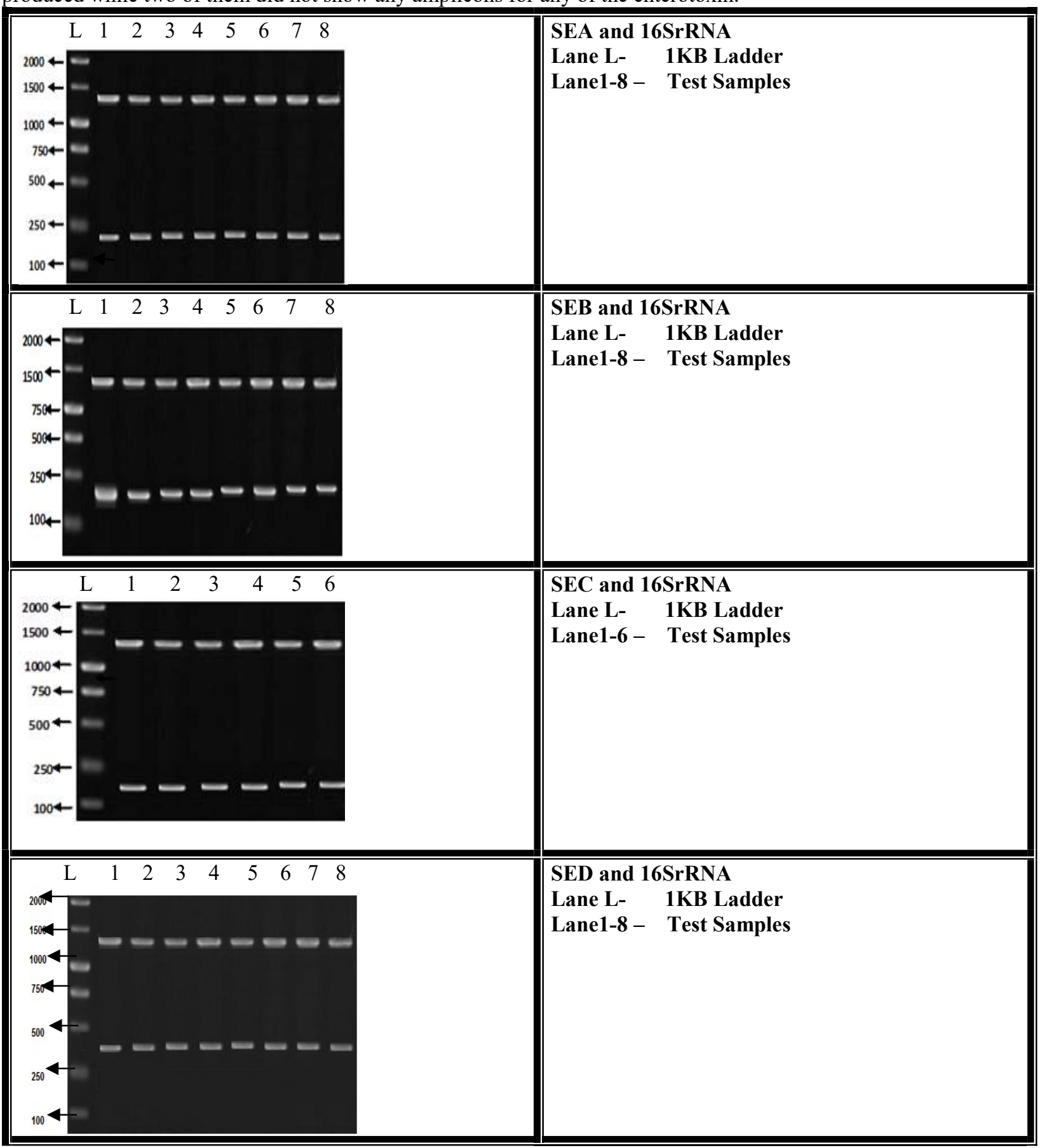




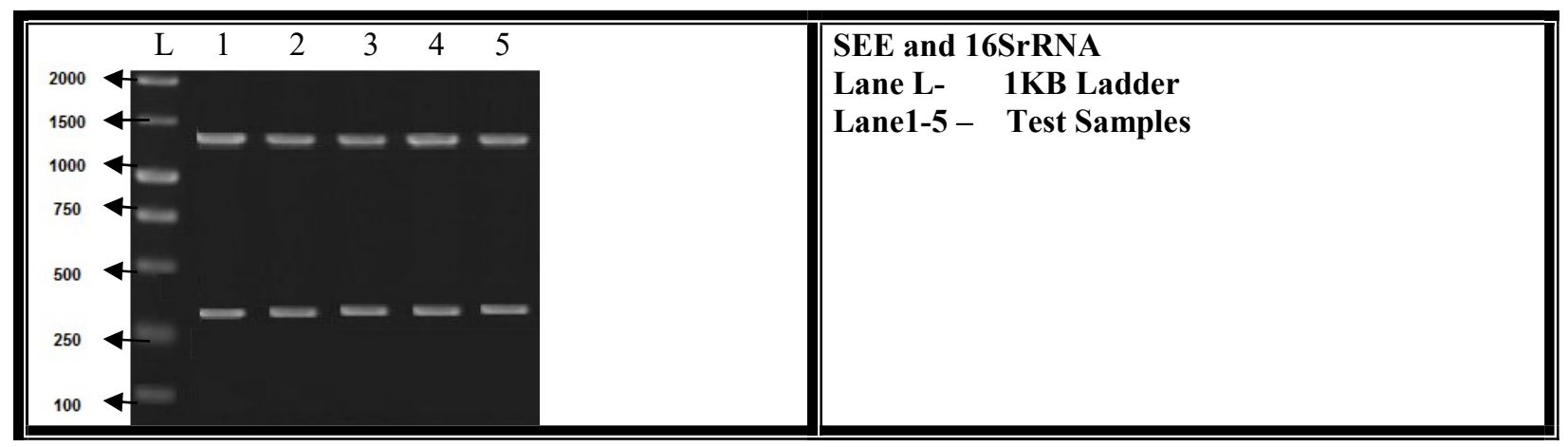

Fig 1: Multiplex PCR Amplicons Showing Toxigenic Strains of Staphylococcus aureus for different Enterotoxins and 16SrRNA

\section{Conclusion}

Food borne infection is currently widespread throughout the world and has evoked a prompt interest and concern for the rapid detection of toxigenic strains of Staphylococcus aureus. The most impressive advantages of PCR based detection method in comparison to the standard microbiological detection method are its speed, sensitivity and specificity and accuracy of the obtained results. Molecular based methods have well-grounded potential to overcome insufficiencies of identification procedures associated with the results based on biochemical characteristics. The purpose of our study was characterization of recovered strains phenotypically by conventional methods and genotypically by PCR for direct detection of S. aureus 16SrRNA gene and staphylococcus enterotoxin genes for SEA, SEB, SEC, SED and SEE. Out of the 59 isolates of Staphylococcus aureus obtained from various food samples, found positive for enterotoxin infection, 15, 21, 6, 12 and 5 were found to be producing SEA, SEB, SEC, SED and SEE respectively further employing that these strains were capable of producing only one type of enterotoxin. Developed PCR techniques on further investigations focus on the application to large scale of clinical samples so that this technique can be used in detecting toxigenic strain of Staphylococcus aureus for public safety concern in foods. Hence the developed mPCR method will help in faster diagnosis of Staphylococcus aureus food poisoning.

\section{References}

1. Bergdoll, M.S.1983. Enterotoxins, p.559-598.In C.S.F. Easmon and C.Adlam(ed), Staphylococci and Staphylococcal infections. Academic Press, Inc., New York.

2. Bohach G.A and P.M.Schlievert. 1987. Nucleotide sequence of the staphylococcal enterotoxin $\mathrm{C} 1$ gene and reletedness to other pyrogenic toxins. Mol.Gen.Genet.209:15-20.

3. Doan C.H and P.M.Davidson 1999. Growth and production of Enterotoxin by Staphylococcus aureus on home style French fries. J.Food Sci.64:913-917

4. Iun Fan Lei et al, (2008): Development of multiplex PCR Method f detection of six common food borne pathogens. Journal of Food and Drug Analysis .Vol 16, No.4. pg 37-43.

5. Johnson L.P., J.J.L Italein and P.M.Schlievert.1986. Streptococcal pyrogenic exotoxin A (Scarlet fever toxin) is related to Staphylococcus aureus enterotoxin B. Mol.Gen.Genet.203:354-356.

6. Marrach,T.,E.F.Fritsch and J.Kappler 1990. The Staphylococcal enterotoxins and their relatives. Sciences 248:705-711.

7. Maria Angeles Argudin, (2010) Food poisoning and Staphylococcus aureus enterotoxin., Toxins 2010,2, 1751-1773.

8. Post D.E.1999.Food borne pathogens (Staphylococcus aureus) Monograph Number 6 oxoid, England.

9. R. Ananthanarayan, C.K. Jayaram Paniker, Textbook of Microbiology. 181-182.

10. Tereza et al., (2009)Rapid and sensitive detection of staphylococcus aureus in Food using Selective Enrichment and Real Time PCR targeting a New Gene Marker. Food Analysis Methods, 2:241-250.

11. YILINGFAN, FENG PAN et al,(2008) Development of mPCR for detection of the genes encoding 16s rRNA, Coagulase, Methicillin resistance and enterotoxin. Journal of rapid methods and automation in Microbiology. 16(2008)394-411. 